https://doi.org/10.5719/aub-g/70.1/8

\title{
PUBLIC PERCEPTION REGARDING AIR POLLUTION IN BUCHAREST DUE TO ROAD TRANSPORT AND THE OPPORTUNITY OF TRAFFIC RESTRICTION FOR POLLUTING VEHICLES
}

\author{
VASILE POPA ${ }^{1}$, IONUȚ ȘANDRIC ${ }^{1}$, RADU IRIMIA $^{1}$, OCTAVIAN COCOȘ$^{1}$
}

\begin{abstract}
Poor air quality is a major risk for health and environment. This is the reason why the local public administration authorities should take urgent measures to cut down air pollution, which is caused especially by car traffic. This research aims at investigating the public perception regarding air pollution in Bucharest City and at assessing the contribution of car traffic to the general pollution, in order to come up with relevant information for implementing a policy meant to restrict the traffic of polluting vehicles. In this respect, 385 people residing in Bucharest and Ilfov County were interviewed. Many people in Bucharest perceive air pollution as having a negative impact on human health, and consider that polluting vehicles are a major cause for the poor air quality in the city. The vast majority of the surveyed population considered that urgent measures should be taken to reduce air pollution, including restricting the traffic of polluting vehicles.
\end{abstract}

Keywards: air pollution, polluting vehicles, traffic restriction, Bucharest, Romania

\section{Introduction}

Air pollution is one of the worst problems facing human society, and especially the big cities. The transport, in general, and the road one, in particular, is a significant source of global air pollution through emissions of nitrogen oxides $\left(\mathrm{NO}_{x}\right)$, particulate matter $(\mathrm{PM})$, carbon

\footnotetext{
${ }^{1}$ University of Bucharest, Faculty of Geography, E-mail: popavasile2005@yahoo.com; sandricionut@yahoo.com; raduirimia@yahoo.com; octaviancocos@yahoo.com.
} 
monoxide (CO) or hydrocarbons; it contributes by more than $24 \%$ to the $\mathrm{CO}_{2}$ emissions (IEA 2017). There are also emissions due to tire and brake wear or to road dust. Although during the last decades there have been significant drops, in 2015 the road transport in the EU countries contributed by $11 \%$ to the PM10 emissions, $11 \%$ to the $\mathrm{PM}_{2.5}$ emissions and $39 \%$ to the $\mathrm{NO}_{x}$ emissions (EEA 2017).

Air pollution affects population health, economy and natural environment. Pollutants, such as $\mathrm{PM}_{2.5}, \mathrm{NO}_{x}$ and tropospheric ozone $\left(\mathrm{O}_{3}\right)$, cause respiratory, cardiovascular and cancer diseases. Many studies have shown the link between exposure to air pollution and human health: Peng et al. 2009; Jerrett et al. 2009; Brook et al. 2010, Bell et al. 2010; Guxens and Sunyer 2012; Turner et al. 2016. According to the EEA (2019), around one in eight EU citizens living in urban areas is exposed to levels of air pollutants that exceed one or more air quality standards. Moreover, according to the stricter WHO guidelines, up to $96 \%$ of the EU citizens are exposed to levels considered to be harmful to the health when it comes to one or more air pollutants. In 2016, around 4.2 million people worldwide prematurely died as a result of exposure to outdoor air pollution (WHO 2018). At the same time, air pollutants have negative effects on climate, biodiversity, water, soil, agricultural crops (including through ground-level ozone) or buildings. Greenhouse gas emissions, especially carbon dioxide $\left(\mathrm{CO}_{2}\right)$, contribute to global warming. The transport contribution to $\mathrm{CO}_{2}$ emissions is $24 \%$ (IEA 2017). The dependancy on fossil fuels explains why the road sector has a major share to the greenhouse gas emissions, being one of the few sectors of activity in which emissions have continued to increase (Chapman 2007).

So far, various measures have been taken to reduce emissions from road traffic, such as technological development or traffic regulation, including the ban on polluting cars. The first emission standards were introduced in the USA in the years 1960-1970, the vehicles being equipped with oxidation catalyst. In Europe, Sweden and Switzerland were the first countries to introduce emission standards in 1976 and 1982, respectively (Colvile et al 2001). Recently, on the European and North American political agenda, slong with urban air quality issue, climate change has been added. 
In 1989, a program was introduced in Mexico City, called Hoy No Circula (Day without a Car), which banned most drivers from using their vehicles on a particular working day based on the latest figure on the vehicle's plate number (Davis 2008). Subsequently, such policies were adopted in São Paulo and Bogotá (Lin et al. 2011). Beijing and the neighboring city, Tianjin, also implemented traffic restrictions during the 2008 Olympic Games. Some studies (Eskeland and Feyzioglu 1997; Davis 2008; Lin et al. 2011) show that driving restrictions based on the vehicle license plate do not lead to an overall improvemnet of air quality.

In 2003, London became the first major European city to introduce a city center access fee (congestion charge). Subsequently, several European cities (Milan, Paris, Brussels, Madrid, Barcelona, Stuttgart, Frankfurt, Hamburg, Oslo, Stockholm, Gothenburg, Athens, Rome) have introduced or announced that they will introduce in the near future their own tax systems, as well as restrictions or traffic bans for polluting vehicles, especially the diesel ones (DW 2018; Business Insider 2019; El País 2019; Euronews 2019). In September 2018, for instance, the Wiesbaden Court of Justice decided to ban, starting with February 2019, the diesel vehicles with emission standards below Euro 5 (and from September 2019 even the Euro 5 ones), as well as the petrol vehicles below Euro 3, in the central area of Frankfurt City. This was done at the request of the environmental group Deutsche Umwelthilfe, because the specified types of vehicles exceeded the maximum safety levels of nitrogen oxides. And Frankfurt is not the only city in Germany that did such a thing. Since May 2018, the city of Hamburg has imposed traffic restrictions in the central district of Altona for vehicles that do not meet the Euro 6 emission standards (DW 2018).

A similar project entered the public debate in Bucharest in August 2019. In October 2019, the local public authorities announced they will ban polluting cars in the city center starting with 2020. Thus, from January 2020, the cars under Euro 3 standards should have been banned in the city center, while those under Euro 4 should have been allowed to drive only if they paid for the Oxigene vignette. The restriction was meant to apply from Monday to Friday between 7-22, except on public holidays. However, this measure was canceled in March 2020, according to a decision of the General Council of Bucharest City, following a 
survey conducted by the mayor on his Facebook page, in which most of the comments were negative!

\section{Materials and methods}

The study was conducted in Bucharest, the most populated and the largest economic center in Romania. The city has an area of $240 \mathrm{~km}^{2}$ and a population of 2.1 million inhabitants (INS 2019). In Bucharest, the air quality monitoring network has 8 autonomous fixed stations, which are managed by the National Agency for Environmental Protection. The data from the stations can be viewed on the governmental website calitateaer.ro. There is also an independent air quality monitoring network, consisting of 14 sensors, which became operational on October 1, 2018. The data is available to the public on the website https://airly.eu/map/en/ or in the Airly smartphone application. Bucharest is one of the cities with the busiest traffic, being on the 3rd place in Europe, after Moscow and Istanbul, and on the 11th place worldwide (TomTom Traffic Index 2018). Due to the fact that the levels of air pollution with suspended dust in Bucharest were frequently exceeded, in 2018 the European Commission sent Romania to the EU Court of Justice for non-compliance with air quality standards.

The survey was open to all persons interested in air quality in Bucharest, eihter by accessing the online questionnaire (provided by https://arcg.is/08qD44) or by filling in printed copies distributed directly. The participation of the 385 people was voluntary, the implementation period being May-December 2019. The questionnaire was designed to identify the views and attitudes of the population regarding air pollution and the need to reduce pollution, including by restricting the traffic of polluting vehicles. It was structured in several parts, which aimed at the following issues: participants' basic knowledge about air pollution, perception of pollution sources, methods of exposure, effects on human health, actions/measures to reduce pollution, and general characteristics of participants. 


\section{Results}

General information about the participants. Of the 385 survey participants, $44 \%$ were male and $56 \%$ female (Table 1). Most of them were between 18 and 35 years old $(75 \%)$ and were higher education graduates $(69 \%)$. Almost half of the participants were students, followed by employees in various public institutions.

Table 1

General information about the participants

\begin{tabular}{|c|c|}
\hline Personal data & Percentage \\
\hline $\begin{array}{l}\text { Gender } \\
\text { male } \\
\text { female } \\
\text { I do not declare }\end{array}$ & $\begin{array}{c}43.6 \% \\
56.1 \% \\
0.3 \% \\
\end{array}$ \\
\hline $\begin{array}{l}\text { Age } \\
\qquad \begin{array}{l}\text { less than } 18 \\
18-35 \\
36-60 \\
\text { more than } 60\end{array}\end{array}$ & $\begin{array}{c}1 \% \\
75 \% \\
16.2 \% \\
7.8 \%\end{array}$ \\
\hline $\begin{array}{l}\text { Level of education } \\
\text { school } \\
\text { high school } \\
\text { higher education } \\
\text { postgraduate studies } \\
\end{array}$ & $\begin{array}{l}1.6 \% \\
5.8 \% \\
69.1 \% \\
23.5 \% \\
\end{array}$ \\
\hline $\begin{array}{l}\text { Occupational structure } \\
\text { public institutions } \\
\text { private sector employee } \\
\text { freelancer } \\
\text { student } \\
\text { other }\end{array}$ & $\begin{array}{c}23.1 \% \\
22.6 \% \\
1.1 \% \\
49.6 \% \\
3.6\end{array}$ \\
\hline $\begin{array}{l}\text { Place of residence } \\
\text { central area } \\
\text { Neighborhood (mention) } \\
\text { outside the city }\end{array}$ & $\begin{array}{l}15.8 \% \\
70.6 \% \\
13.6 \%\end{array}$ \\
\hline
\end{tabular}


Participants' basic knowledge about air pollution. Survey participants responded in proportion of $98 \%$ that they are concerned about air pollution in the area where they live/work or study, and almost $88 \%$ consider that the level of air pollution in Bucharest is high (Table 2). The biggest concerns are due to emissions of suspended particles. Carbon dioxide, although not a pollutant, is perceived as harmful to the environment because it contributes to global warming (Figure 1).

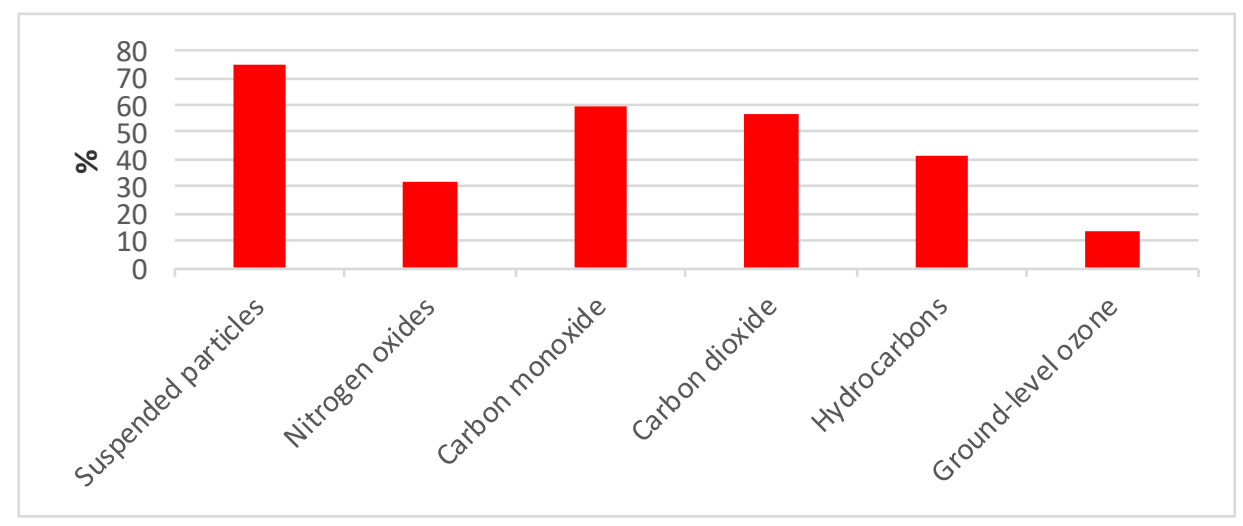

Fig.1. The main air pollutants that worry the people of Bucharest

Participants' basic knowledge about air pollution

\begin{tabular}{|l|l|l|}
\hline \multicolumn{1}{|c|}{ Question } & \multicolumn{1}{|c|}{ Answer } & Percentage \\
\hline $\begin{array}{l}\text { Are you concerned about air } \\
\text { pollution in the area where you } \\
\text { live/work/study? }\end{array}$ & $\begin{array}{l}\text { Yes } \\
\text { No }\end{array}$ & $2 \%$ \\
\hline $\begin{array}{l}\text { How do you rate air pollution in } \\
\text { Bucharest? }\end{array}$ & High & $87.8 \%$ \\
& Moderate & $11.9 \%$ \\
\hline What are the main air pollutants & Suspended particles & $0.3 \%$ \\
that worry you the most? (multiple \\
choices) & Nitrogen oxides \\
& Carbon monoxide & $31.7 \%$ \\
& Carbon dioxide & $59.5 \%$ \\
& Hydrocarbons & $41 \%$ \\
& Ground-level ozone & $14 \%$ \\
\hline
\end{tabular}


Perception of exposure patterns and effects on human health. All survey participants knew that air pollution can have negative effects on human health, environment and economy, and 91.5\% felt that they did not feel comfortable in polluted air (Table 3). Regarding the types of exposure to pollutants, over $97 \%$ of respondents indicated breathing of polluted air, then consumption of contaminated food and contact with soil or other contaminated objects (Figure 2). Regarding the diseases caused by air pollutants, the vast majority indicated lung diseases, and about half mentioned cardiovascular diseases.

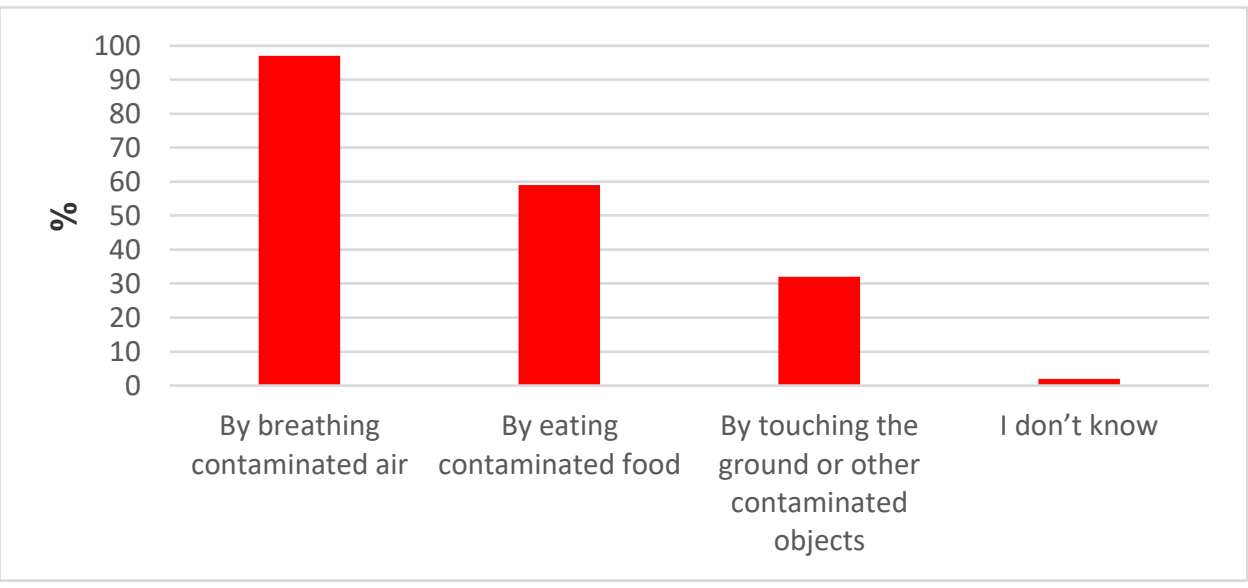

Fig.2. Modes of exposure to air pollution

Table 3

Modes of exposure and effects on human health

\begin{tabular}{|l|l|l|}
\hline \multicolumn{1}{|c|}{ Question } & \multicolumn{1}{|c|}{ Answer } & Percentage \\
\hline $\begin{array}{l}\text { Do you know that air pollution } \\
\text { can have negative effects on } \\
\text { human health, environment } \\
\text { and economy? }\end{array}$ & No & $\begin{array}{l}100 \% \\
0 \%\end{array}$ \\
\hline $\begin{array}{l}\text { Do you feel comfortable in } \\
\text { polluted air? }\end{array}$ & $\begin{array}{l}\text { Yes } \\
\text { No } \\
\text { The sensation is not obvious }\end{array}$ & $\begin{array}{l}2.5 \% \\
91.5 \%\end{array}$ \\
6
\end{tabular}




\begin{tabular}{|c|c|c|}
\hline $\begin{array}{l}\text { Do you know how you are } \\
\text { exposed to air pollutants that } \\
\text { can affect your health? } \\
\text { (multiple choices) }\end{array}$ & $\begin{array}{l}\text { By breathing contaminated air } \\
\text { By eating contaminated food } \\
\text { By touching the ground or other } \\
\text { contaminated objects } \\
\text { I don't know }\end{array}$ & $\begin{array}{l}97.4 \% \\
58.7 \% \\
31.9 \% \\
1.5 \%\end{array}$ \\
\hline $\begin{array}{l}\text { Do you know what diseases } \\
\text { can be caused by air pollution? } \\
\text { (multiple choices) }\end{array}$ & $\begin{array}{l}\text { Lung diseases } \\
\text { Cardiovascular diseases } \\
\text { Neurological diseases } \\
\text { I don't know }\end{array}$ & $\begin{array}{l}97.4 \% \\
48.3 \% \\
31.2 \% \\
1.6 \%\end{array}$ \\
\hline
\end{tabular}

Perception of the role of road transport in air pollution. Almost all those who responded to the questionnaire said that road transport is a major source of pollution for Bucharest, which significantly affects human health (Table 4). The increase in the number of vehicles on the city streets and, implicitly of pollution are due to population growth, poor road infrastructure or inadequate public transport (Figure 3). Diesel cars are considered the most polluting vehicles.

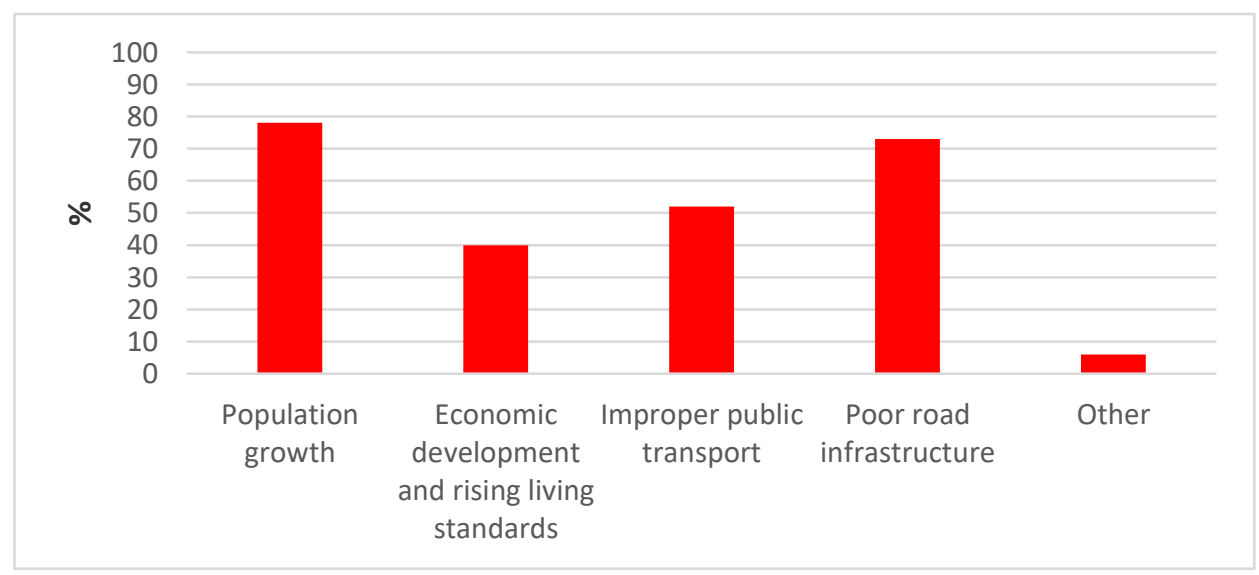

Fig.3. The causes of the increase in the number of vehicles on the city streets and implicitly the increase of pollution 
Table 4

The role of road transport in air pollution

\begin{tabular}{|l|l|c|}
\hline \multicolumn{1}{|c|}{ Question } & \multicolumn{1}{|c|}{ Answer } & Percentage \\
\hline Is road transport a major source of & Yes & $98.2 \%$ \\
pollution in Bucharest? & No & $1 \%$ \\
& I don't know & 0.8 \\
\hline How much is human health & Much & $85.4 \%$ \\
affected by car pollution? & Moderate & $13.8 \%$ \\
& Slightly & $0.8 \%$ \\
\hline The increase in the number of & Population growth & $77.6 \%$ \\
vehicles on the city streets and & Economic development and & $39.7 \%$ \\
implicitly the increase in pollution & rising living standards & \\
are caused by: (multiple choices) & Improper public transport & $52 \%$ \\
& Poor road infrastructure & $72.5 \%$ \\
\hline In road transport, the most & Other & $6 \%$ \\
polluting vehicles are those on: & Piesel fuel & $21.4 \%$ \\
& Petrol & $8.9 \%$ \\
\hline
\end{tabular}

Perception of the involvement of local authorities and the population in reducing air pollution. The majority of the respondents said that both local public authorities and the population are insufficiently involved in solving the air pollution issue in Bucharest (Table 5). Only $12 \%$ mentioned measures taken by the authorities to reduce pollution (widening streets, building roads or parking lots, planting trees). The main means of transport used by the population are public transport and walking. Public transport would be used more often if it were improved.

Table 5

The degree of involvement of local public authorities and the population in reducing air pollution

\begin{tabular}{|l|l|l|}
\hline Question & Answer & Percentage \\
\hline Are the local authorities sufficiently & Yes & $1.6 \%$ \\
involved in solving the problem of air & No & $88 \%$ \\
pollution in Bucharest? & I don't know & $10.4 \%$ \\
\hline
\end{tabular}




\begin{tabular}{|c|c|c|}
\hline $\begin{array}{l}\text { Do you know of any measure taken } \\
\text { by the authorities to reduce air } \\
\text { pollution? }\end{array}$ & $\begin{array}{l}\text { Yes (mention it) } \\
\text { No }\end{array}$ & $\begin{array}{l}12 \% \\
88 \%\end{array}$ \\
\hline $\begin{array}{l}\text { Do you think that the city's } \\
\text { population is sufficiently involved in } \\
\text { maintaining a clean air propitious to } \\
\text { life? }\end{array}$ & $\begin{array}{l}\text { Get involved enough } \\
\text { Not getting involved } \\
\text { enough } \\
\text { I don't know }\end{array}$ & $\begin{array}{l}0.5 \% \\
94 \% \\
5.5 \%\end{array}$ \\
\hline $\begin{array}{l}\text { What are the main travel methods } \\
\text { you use for your daily activities? } \\
\text { (multiple choices) }\end{array}$ & $\begin{array}{l}\text { Public transport } \\
\text { Personal car } \\
\text { Service car } \\
\text { Bike/scooter } \\
\text { Motorcycle } \\
\text { Walking }\end{array}$ & $\begin{array}{l}85.5 \% \\
16.1 \% \\
1.3 \% \\
6.7 \% \\
0.5 \% \\
45.7 \%\end{array}$ \\
\hline $\begin{array}{l}\text { Would you use public transport more } \\
\text { often if it improved? }\end{array}$ & $\begin{array}{l}\text { Yes } \\
\text { No } \\
\text { I don't know }\end{array}$ & $\begin{array}{l}94.3 \% \\
2.1 \% \\
3.6 \%\end{array}$ \\
\hline
\end{tabular}

Perception of measures to combat air pollution as a result of road transport. The vast majority of the surveyed population considered that urgent measures should be taken to reduce air pollution, including restricting the traffic of polluting vehicles (Table 6). Almost $24 \%$ were of the opinion that traffic restriction should be done only in the central area, and $10 \%$ said that only between 8.00 and 20.00 hours (Figure 4). Regarding the vehicles that should be banned from traffic, $37 \%$ of the respondents mentioned those with emission standards below Euro 3, and $22 \%$ those with pollution standards below Euro 4 . Almost $30 \%$ of those who filled in the questionnaire considered that traffic restriction for the vehicles with emission standards below Euro $5(17 \%)$ and below Euro $6(14 \%)$ is a must. This percentage is close to that of Euro 5 and Euro 6 vehicle owners, i.e. $28.5 \%$. The necessary solutions to reduce air pollution due to car transport are the following: prioritizing, modernizing and expanding the public transport (73\%), building a modern ring road (61\%), expanding and modernizing the road infrastructure $(57 \%)$ or streamlining the traffic. 


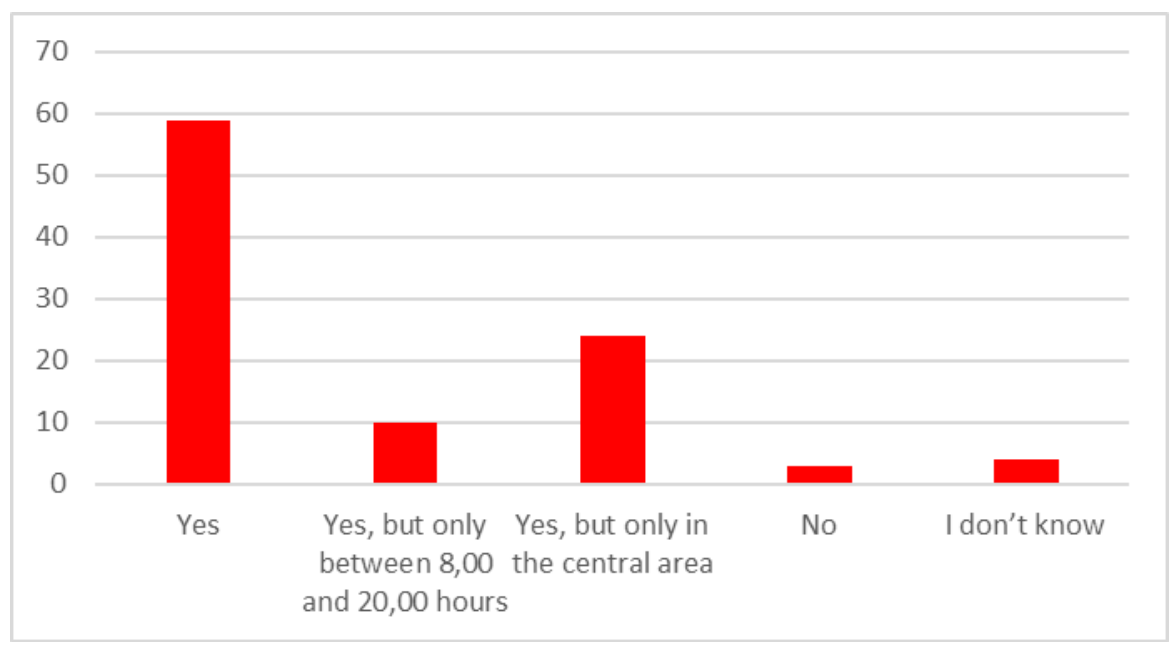

Fig.4. The decision to restrict polluting car traffic in Bucharest

Table 6

Measures to combat air pollution as a result of road transport

\begin{tabular}{|c|c|c|}
\hline Question & Answer & Percentage \\
\hline $\begin{array}{l}\text { Do you think that } \\
\text { urgent measures } \\
\text { should be taken to } \\
\text { reduce air pollution? }\end{array}$ & $\begin{array}{l}\text { Yes } \\
\text { No } \\
\text { I don't know }\end{array}$ & $\begin{array}{c}96.9 \% \\
0.3 \% \\
2.8 \%\end{array}$ \\
\hline $\begin{array}{l}\text { Do you consider a } \\
\text { decision to restrict } \\
\text { polluting car traffic } \\
\text { in Bucharest is } \\
\text { necessary? }\end{array}$ & $\begin{array}{l}\text { Yes } \\
\text { Yes, but only between } 8,00 \text { and 20,00 hours } \\
\text { Yes, but only in the central area } \\
\text { No } \\
\text { I don't know }\end{array}$ & $\begin{array}{l}58.7 \% \\
10.4 \% \\
23.9 \% \\
3.4 \% \\
3.6 \%\end{array}$ \\
\hline $\begin{array}{l}\text { If you consider the } \\
\text { decision necessary, } \\
\text { which cars should } \\
\text { be banned? }\end{array}$ & $\begin{array}{l}\text { All vehicles with emission standards below } \\
\text { Euro } 3 \\
\text { Those on diesel fuel with emission standards } \\
\text { below Euro } 4 \\
\text { Those on petrol gas with emission standards } \\
\text { below Euro } 4 \\
\text { All vehicles with emission standards below } \\
\text { Euro } 4 \\
\text { Those on diesel with emission standards } \\
\text { below Euro } 5 \\
\text { Those on petrol/gas with emission standards }\end{array}$ & $\begin{array}{l}37 \% \\
6.5 \% \\
3.5 \% \\
22 \% \\
6 \% \\
1.4 \%\end{array}$ \\
\hline
\end{tabular}




\begin{tabular}{|c|c|c|}
\hline & $\begin{array}{l}\text { below Euro } 5 \\
\text { All vehicles with emission standards below } \\
\text { Euro } 5 \\
\text { Those on diesel emission standards below } \\
\text { Euro } 6 \\
\text { Those on petrol/gas with emission standards } \\
\text { below Euro } 6 \\
\text { All vehicles with emission standards below } \\
\text { Euro } 6\end{array}$ & $\begin{array}{l}9.6 \% \\
2.2 \% \\
2.2 \% \\
9.6 \%\end{array}$ \\
\hline Do you own a car? & $\begin{array}{c}\text { Yes } \\
\text { No }\end{array}$ & $\begin{array}{l}41.9 \% \\
58.1 \% \\
\end{array}$ \\
\hline $\begin{array}{l}\text { The car you } \\
\text { own/drive has } \\
\text { emission } \\
\text { standards: }\end{array}$ & $\begin{array}{l}\text { Euro } 6 \\
\text { Euro } 5 \\
\text { Euro } 4 \\
\text { Below Euro } 4 \\
\text { I do not own/drive a vehicle }\end{array}$ & $\begin{array}{c}8.7 \% \\
19.8 \% \\
14.7 \% \\
2.6 \% \\
54.2 \% \\
\end{array}$ \\
\hline $\begin{array}{l}\text { What other solutions } \\
\text { to reduce air } \\
\text { pollution caused by } \\
\text { car transport do } \\
\text { you consider } \\
\text { necessary? } \\
\text { (multiple choices) }\end{array}$ & $\begin{array}{l}\text { Introduction of a city center access fee for } \\
\text { polluting cars } \\
\text { Prioritization, modernization and expansion } \\
\text { of public transport } \\
\text { Expansion and modernization of road } \\
\text { infrastructure } \\
\text { Enhancing traffic flow } \\
\text { Construction of a modern ring road } \\
\text { Free or cheap parking at the entrance to } \\
\text { Bucharest } \\
\text { Other }\end{array}$ & $\begin{array}{c}46 \% \\
73 \% \\
57 \% \\
49.6 \% \\
61 \% \\
47 \% \\
2.6 \%\end{array}$ \\
\hline
\end{tabular}

\section{Discussion}

The relationship between air pollution, car traffic and health is well known, especially among the educated people. Such studies are needed in making decisions about public health and environmental protection. In order to improve air quality, it is necessary to strengthen the knowledge of the population about air pollution caused by motor vehicles and to increase the involvement of public authorities and the population. The survey participants were mainly represented by young people, students, university graduates or postgraduates, which hold an important share of the Bucharest's population, which is the largest 
university and economic center of Romania, attracting annually many young people.

The study aimed at quantifying the participants' knowledge about air pollution, its relationship with road transport and the effects on human health. Thus, $88 \%$ of the participants mentioned that the level of air pollution in Bucharest is high, which is consistent with the current situation. According to the National Environmental Protection Agency, in Bucharest there were several exceedances of the threshold values for nitrogen dioxide, particulate matter ( $\left.\mathrm{PM}_{10}, \mathrm{PM}_{2.5}\right)$, ozone and benzene, especially at traffic stations. For $\mathrm{NO}_{2}$, the annual limit value for the protection of the population's health is exceeded over a large area of Bucharest, especially in the center and along the busy roads. For PM10, the limit value of the average annual concentration was exceeded on small areas in north, center and southeast. High values of PM10 concentrations $\left(35-40 \mu \mathrm{g} / \mathrm{m}^{3}\right)$ were recorded over large areas in the city center, in the areas adjacent to it and along the busy roads. For PM2.5, the annual average concentration threshold was exceeded over large areas in all the sectors of the city. The high level of air pollution in Bucharest was also highlighted by other studies: Constantin et al. 2012; Istrate et al. 2014; Ștefan et al. 2015; Iorga, Bălăceanu and Ștefan 2015.

The fact that the vast majority of participants specified that vehicles are a major source of air pollution in Bucharest is confirmed by the official data. According to the Integrated Plan for Air Quality in Bucharest, the road traffic contributes by $66.3 \%$ to the total $\mathrm{NO}_{\mathrm{x}}$ emissions, by $47.3 \%$ to the $\mathrm{PM}_{2.5}$ emissions and by $58.6 \%$ to the $\mathrm{PM}_{10}$ emissions. At the same time, road traffic also contributes by $64.5 \%$ to the total benzene emissions. Although most of the survey participants agreed that polluting car traffic needs to be restricted, many of them considered that only the vehicles with emission standards below Euro 3 or Euro 4 should be banned (Table 5). Under the circumstances, air pollution would not be significantly reduced. According to the Integrated Plan for Air Quality in Bucharest (2018), in terms of the fuel used, the vehicles with Euro 4 and Euro 3 emission standards have the largest shares (Figures 5 and 6). The highest $\mathrm{NO}_{\mathrm{x}}$ emissions associated with petrol cars come from Euro $4(31 \%)$ vehicles, followed by those below Euro $2(26 \%)$ and by the Euro 2 ones $(21 \%)$, while for the cars 
equipped with diesel engines the highest emissions are associated with Euro $4(42 \%)$ and Euro $3(32 \%)$ classes. PM10 emissions are mainly attributed to cars equipped with diesel engines (over 97\%); at the level of this segment the largest share of emissions comes from the engines with Euro 3 (34\%) and Euro 4 (55.5\%) emission standards.

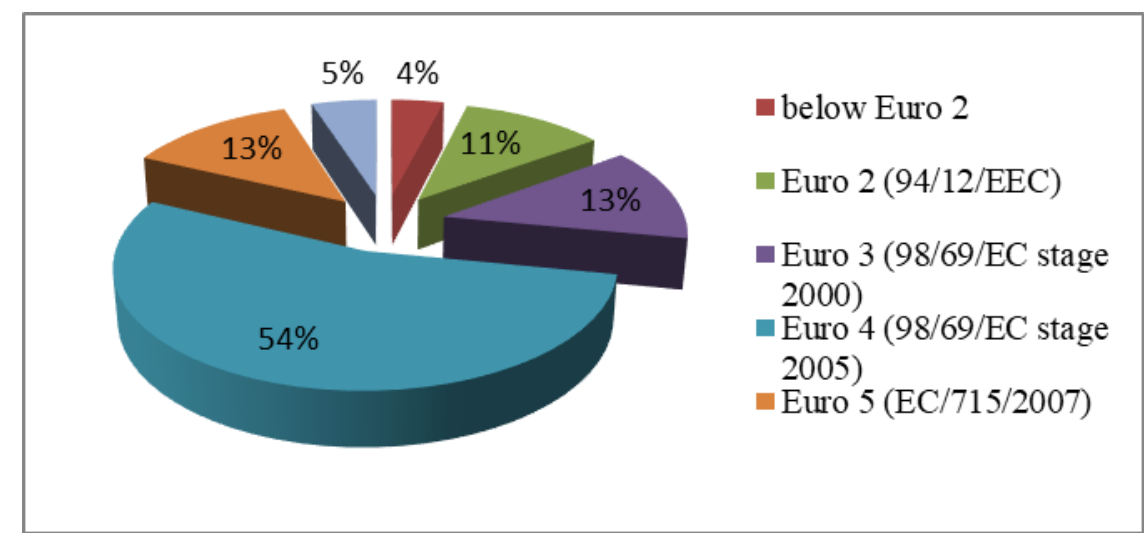

Fig. 5. The distribution of petrol engine cars depending on their technology

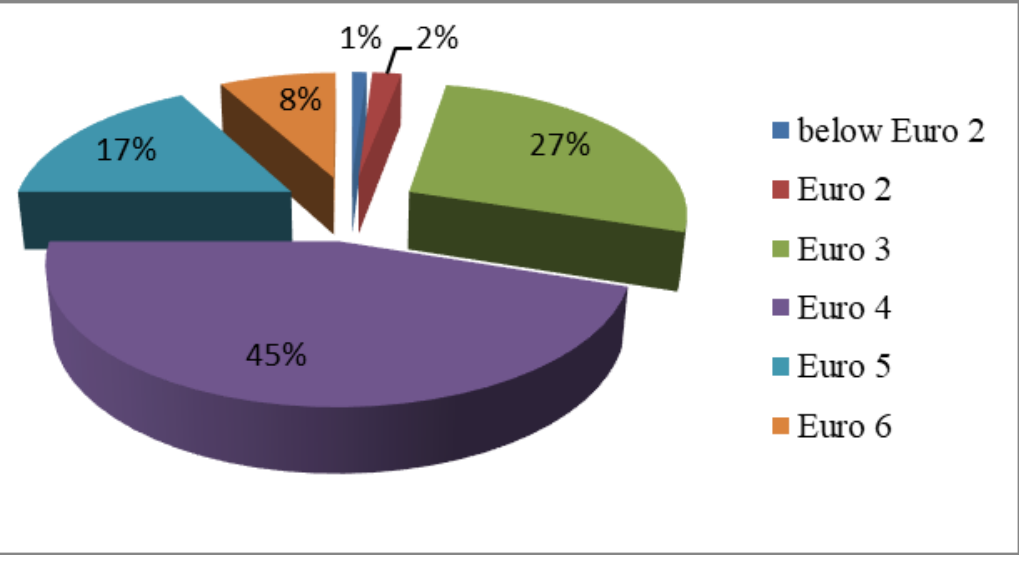

Fig. 6. The distribution of diesel engine cars depending on their technology 


\section{Conclusions}

This study explored the public's perception regarding air pollution issues and the need to ban polluting vehicles, in order to provide useful information for public authorities and population. It is clear that many people in Bucharest perceive air pollution as having a negative impact on human health, and consider that polluting vehicles are a major cause for the poor air quality in the city. There is a major concern among the people regarding the air quality in the areas where they live, work or study, $88 \%$ of the respondents considering that the level of air pollution in Bucharest is high. The level of involvement of local authorities and the population in reducing air pollution is perceived as insufficient, $97 \%$ of the participants considering that urgent action needs to be taken in this regard. As far as the ban of polluting vehicles is concerned, the participants in the survey supported the ban of the vehicles with emission standards below Euro 3 and Euro 4. Although the number of participants over the age of 60 was lower, the research results can be considered useful. Young people, especially the educated, are the most active category in the city. Their involvement is essential and they can significantly influence the city's future environmental policies. Future research, with a wider range of respondents, will provide a more comprehensive picture on this topic.

\section{BIBLIOGRAPHIE}

ANPM (Agenția Națională pentru Protecția Mediului), Raport privind calitatea aerului în România în anul 2017. http://www.anpm.ro/documents/12220/2723600/ Raport+calitatea+aerului+in+Romania+in+ 2017, viewed 22 February 2020, <pdf/83134206-b1d4-47ef-83d1-4e9e2e2e8282>.

Bell, ML, Belanger, K et al. 2010, Prenatal exposure to fine particulate matter and birth weight: variations by particulate constituents and sources, Epidemiology 21 (6), 884-891.

Brody, SD, Peck, BM, Highfield, WE 2004, Examining localized patterns of air quality perception in Texas: A spatial and statistical analysis, Risk Analysis 24, 1561-1574.

Brook, RD, Rajagopalan, S, Pope III, CA, Brook, JR, Bhatnagar, A, Diez-Roux, AV et al. 2010, Particulate matter air pollution and cardiovascular disease: an update to the scientific statement from the American heart association, Circulation 121, 2331-2378. 
Business Insider 2019, 15 major cities around the world that are starting to ban cars, by A. Bendix, Jan. 12, viewed 23 February 2020, <https://www.businessinsider.com/ cities-going-car-free-ban-2018-12>.

Chapman, L 2007, Transport and climate change: a review, Journal of Transport Geography 15, 354-367.

Claeson, AS, Lidén, E, Nordin, M, Nordin, S 2013, The role of perceived pollution and health risk perception in annoyance and health symptoms: a population-based study of odorous air pollution, Int. Arch. Occup. Environ. Health 86 (3), 367-374.

Colvile, RN, Hutchinson, EJ, Mindell, JS, Warren, RF 2001, The transport sector as a source of air pollution, Atmospheric Environment 35 (9) 1537 - 1565.

Davis, LW 2008, The Effect of Driving Restrictions on Air Quality in Mexico City, Journal of Political Economy 116 (1), 38-81.

DW 2018, Stuttgart to introduce diesel driving ban in 2019, 11.07, viewed 20 May 2020, $<$ https://www.dw.com/en/stuttgart-to-introduce-diesel-driving-ban-in-2019/a44634246>.

Elliott, SJ, Cole, DC., Krueger, P, Voorberg, N, Wakefield, S 1999, The power of perception: Health risk attributed to air pollution in an urban industrial neighbourhood, Risk Analysis19, 621-634.

EEA (European Environment Agency) 2019, Outdoor air quality in urban areas, 8 May 2019, viewed 20 May 2020, <https://www.eea.europa.eu/airs/2018/environmentand-health/outdoor-air-quality-urban-areas\#tab-based-on-indicators $>$.

EEA 2017, Air quality in Europe - 2017 report, EEA Report No 13/2017, viewed 10 february 2020, <https://www.eea.europa.eu/ publications/air-quality-in-europe2017>.

El País 2019, Barcelona to cut traffic by $7 \%$ next year with a ban on most-polluting vehicles, by Clara Blanchar, 18 Mar, viewed 22 January 2020, <https://elpais.com/ elpais/2019/03/16/inenglish/1552760325_812520.html>.

El País 2018, Madrid City Hall bans older, more polluting cars from center, by Gloria Rodríguez-Pina, Madrid 12 Dic, viewed 22 January 2020, <https://elpais.com/ elpais/2018/12/12/inenglish/ 1544607623_776238.html>.

EU 2008, Directive 2008/50/EC of the European Parliament and of the Council of 21 May 2008 on ambient air quality and cleaner air for Europe, Oficial Journal L 152, 11.6.2008, 1-44.

Euronews 2019, What are European cities doing to tackle air pollution? by C. Harris, R. Cereceda, M. Armstrong, 27/02/2019, viewed 16 February 2020, $<$ https://www.euronews.com/2019/02/27/what-are-european-cities-doing-totackle-air-pollution>.

Eskeland, SG, Feyzioglu, T 1997, Rationing Can Backfire: The "Day without a Car" in Mexico City, The World Bank Economic Review 11(3), 383-408.

Guo, Y, Liu, F, Lu, Y, Mao, Z, Lu, H, Wu, Y et al. 2016, Factors affecting parent's perception on air quality-from the individual to the community level, International Journal of Environmental Research and Public Health 13 (5), 493-507.

Guxens, M, Sunyer, J 2012, A review of epidemiological studies on neuropsychological effects of air pollution, Swiss Med. Wkly. 141. 
Howel, D, Moffatt, S, Bush, J, Dunn, CE, Prince, H 2003, Public views on the links between air pollution and health in Northeast England, Environmental Research 91, 163-171.

INS (Institutul Național de Statistică), Direcția Regională de Statistică a Municipiului București. http://www.bucuresti.insse.ro/ produse-si-servicii/statistici-regionale/ (2.11.2019)

IEA (International Energy Agency) 2017, CO2 emissions from fuel combustion, Highlights, OECD/IEA, viewed 18 May 2020, <https://www.iea.org/publications/ freepublications/publication/CO2EmissionsfromFuelCombustionHighlights20 17.pdf $>$.

Jacquemin, B, Sunyer, J, Forsberg, B, Götschi, T, Bayer-Oglesby, L, Ackermann-Liebrich, U, et al. 2007, Annoyance due to air pollution in Europe, International Journal of Epidemiology 36, 809-820.

Jerrett, M, Burnett, RT, Pope III, CA, Ito, K, Thurston, G, Krewski, D, Shi, Y, Calle, E, Thun, M 2009, Long-term ozone exposure and mortality, New England Journal of Medicine 360,1085-1095.

Iorga, G, Bălăceanu, Raicu, C, Ștefan, S 2015, Annual air pollution level of major primary pollutants in Greater Area of Bucharest, Atmospheric Pollution Research 6 (5), 824-834.

Istrate, IA, Oprea, T, Rada, EC, Torretta, V 2014, Noise And Air Pollution From Urban Traffic, WIT Transactions on Ecology and the Environment 191, 1381-1389.

Lin, CYC, Zhang, W, Umanskaya VI 2011, The Effects of Driving Restrictions on Air Quality: São Paulo, Bogotá, Beijing, and Tianjin, Selected Paper prepared for presentation at the Agricultural \& Applied Economics Association's 2011 AAEA \& NAREA Joint Annual Meeting, Pittsburgh, Pennsylvania, July 24-26, viewed 12 february 2020, <https://core.ac.uk/download/pdf/6620767.pdf >.

Observatorul Român de Sănătate 2018, Clasamentul eficienței împotriva poluării, noiembrie 2018, viewed 7 June 2020, <http://health-observatory.ro/wpcontent/uploads/2018/11/raport_ORS_poluare_27 nov.pdf $>$.

Oltra, C, Sala, R 2014, A review of the social research on public perception and engagement practices in urban air pollution, Informes Técnicos Ciemat, Departamento de Medio Ambiente, viewed 8 June 2020, <https://www.osti.gov/ etdeweb/servlets/purl/22225183>.

Smallbone, K 2012, Individuals' interpretation of air quality information, Follow up investigation into the proposed airquality health advice, School of Environment and Technology, University of Brighton, Brighton, BN1 2GJ, 1-56.

Peng, RD, Bell, ML, et al. 2009, Emergency admissions for cardiovascular and respiratory diseases and the chemical composition of fine particle air pollution, Environ. Health Perspect 117 (6), 957-963.

Planul Integrat de Calitate a Aerului în Municipiul București 2018-2022, Consiliul General al Municipiului București, viewed 19 May 2020, <http://apmbuc.anpm.ro/ documents/16241/38124058/plan_integrat_calitate_aer_buc_2018_2022.pdf/1e5f2f6 1-41b0-49f2-bfaf-4b542b31158a>. 
Reames, TG, Bravo, MA 2019, People, place and pollution: Investigating relationships between air quality perceptions, health concerns, exposure, and individual- and area-level characteristics, Environment International 122, 244-255.

Ștefan, S, Bârlădeanu, R, Andrei. S, Zagar, L 2015, Study of air pollution in Bucharest, Romania during 2005 - 2007, Environmental Engineering and Management Journal 14 (4), 809-818.

Tomtom Trafic Index 2018, viewed 15 February 2020, <https:/www.tomtom.com/ en_gb/traffic-index/ranking $>$.

Turner, MC, Jerrett, M, Pope III, CA, Krewski, D, Gapstur, SM, Diver, WR, Beckerman, BS et al. 2016, Long-term ozone exposure and mortality in a large prospective study, Am. J. Respir. Crit. Care Med. 193, 1134-1142.

Wakefield, SE, Elliott, SJ, Cole, DC, Eyles, JD 2001, Environmental risk and (re) action: air quality, health, and civic involvement in an urban industrial neighbourhood, Health Place 7 (3), 163-177.

WHO (World Health Organization) 2018, Ambient (outdoor) air quality and health, viewed 13 April 2020, <https:/www.who.int/news-room/fact-sheets/detail/ ambient-(outdoor)-air-quality-and-health>. 